\title{
Implanted Medical Device
}

National Cancer Institute

\section{Source}

National Cancer Institute. Implanted Medical Device. NCI Thesaurus. Code C80457.

A finding referring to a medical device that has been placed in the body, usually during a surgical procedure. 